\title{
PENGARUH KOMUNIKASI ORGANISASI DAN PENGEMBANGAN GURU TERHADAP ETOS KERJA GURU
}

\author{
Edi
}

SMP Negeri SATAP 2 Losarang, edi12345@gmail.com

\begin{abstract}
ABSTRAK
Perhatian utama pembahasan dalam penelitian ini adalah menyangkut komunikasi organisasi dan pengembangan guru serta pengaruhnya terhadap etos kerja guru. Metode penelitian menggunakan metoda survey terhadap guru. Teknik pengumpulan data, selain melaksanakan observasi langsung, mengadakan wawancara dengan pihak terkait, dan menyebarkan. Hasil penelitian menyatakan bahwa: (1) Terdapat pengaruh yang positif dan signifikan komunikasi organisasi terhadap etos kerja guru (2) Terdapat pengaruh yang positif dan signifikan pengembangan guru terhadap etos kerja guru SMP Negeri di Sektor 3 Kecamatan Jatibarang Kabupaten Indramayu (3) Terdapat pengaruh yang positif dan signifikan komunikasi organisasi dan pengembangan guru secara simultan terhadap etos kerja guru. Penulis menyarankan, bahwa: (1) Masih perlu ditingkatkan komunikasi organisasi lagi dengan mencipakan alur komunikasi yang lebih efektif di dalam organisasi sekolah (2) Sesuai hasil penelitian bahwa pengembangan guru berpengaruh secara signifikan terhadap etos kerja guru. Oleh karena itu untuk meningkatkan etos kerja guru dapat dilakukan dengan cara meningkatkan pengembangan guru melalui komunikasi yang baik, pelatihan, MGMP, organisasi guru, pemberian tanggung jawab yang jelas dan memberikan pengakuan atau apresiasi terhadap guru yang berprestasi.
\end{abstract}

Kata kunci: Komunikasi Organisasi, Pengembangan guru, Etos Kerja

\begin{abstract}
The main concern of the discussion in this research is concerning organizational communication and teacher development and its influence on the work ethic of teachers. The research method uses a survey method of teachers. Data collection techniques, in addition to carrying out direct observation, conducting interviews with relevant parties, and disseminating. The results of the study stated that: (1) There was a positive and significant influence of organizational communication on the teacher's work ethic (2) There was a positive and significant effect on teacher development on the work ethic of the State Junior High School teachers in Sector 3 Jatibarang District, Indramayu Regency (3) There was a significant influence positive and significant organizational communication and teacher development simultaneously towards the teacher's work ethic. The author suggests, that: (1) Organizational communication still needs to be improved again by creating more effective communication channels within school organizations (2) According to the results of research that teacher development significantly influences the work ethic of teachers. Therefore, to improve the teacher's work ethic can be done by increasing teacher development through good communication, training, MGMP, teacher organization, giving clear responsibilities and giving recognition or appreciation to teachers who excel
\end{abstract}

Key words: Organizational Communication, Teacher Development, Work Ethic 


\section{PENDAHULUAN}

Pendidikan adalah usaha sadar untuk menyiapkan peserta didik melalui kegiatan bimbingan, pengajaran, dan atau latihan bagi peranannya di masa yang akan datang (UU SPN No. 20 Tahun 2003). Dengan tidak bermaksud mengecilkan kontribusi komponen yang lainnya, komponen tenaga kependidikan atau guru merupakan salah satu faktor yang sangat esensi dalam menentukan kualitas peserta didiknya.

Peningkatan mutu pendidikan diarahkan untuk meningkatkan kualitas manusia Indonesia seutuhnya melalui olah hati, olah pikir, olah rasa dan olah raga agar memiliki daya saing dalam menghadapi tantangan global. Dalam upaya peningkatan mutu, Pemerintah memberikan arahan tentang perlunya disusun dan dilaksanakan delapan standar nasional pendidikan, yaitu: standar isi, standar proses, standar kompetensi lulusan, standar pendidik dan tenaga kependidikan, standar sarana dan prasarana, standar pengelolaan, standar pembiayaan, dan standar penilaian pendidikan (Pemendiknas No 22 Tahun $2006: 3$ ).

Usaha untuk menciptakan guru yang profesional, pemerintah telah membuat aturan persyaratan untuk menjadi guru. Dalam pasal 8 Undang Undang No.14 tahun 2005 tentang guru dan dosen menyebutkan bahwa guru wajib memiliki kualifikasi akademik, kompetensi, sertifikat pendidik, sehat jasmani dan rohani, serta memiliki kemampuan untuk mewujudkan tujuan pendidikan nasional. Namun dalam kenyataannya masih sedikit guru yang memenuhi syarat tersebut.

UU No. 14 Tahun 2005 Bab IV pasal 20 (a) tentang guru dan dosen menyatakan bahwa standar prestasi kerja guru dalam melaksanakan tugas keprofesionalannya, guru berkewajiban merencanakan pembelajaran, melaksanakan proses pembelajaran yang bermutu serta menilai dan mengevaluasi hasil pembelajaran. Tugas pokok guru tersebut yang diwujudkan dalam kegiatan belajar mengajar merupakan bentuk kinerja guru.

Menurut Permendiknas Nomor 16 Tahun 2007 Pasal (1) Setiap guru wajib memenuhi standar kualifikasi akademik dan kompetensi guru yang berlaku secara nasional. Kompetensi guru diartikan sebagai seperangkat pengetahuan, ketrampilan dan perilaku yang harus dimiliki, dihayati, dan dikuasai oleh guru dalam melaksanakan 
tugas keprofesionalannya. Hal ini sesuai dengan Keputusan Mendiknas No. 045/U/2002 yang menjelaskan bahwa kompetensi adalah seperangkat tindakan cerdas, penuh tanggung jawab yang dimiliki seseorang sebagai syarat untuk dianggap mampu oleh masyarakat dalam melaksanakan tugas-tugas sesuai dengan pekerjaan tertentu. Pasal 10 Undang Undang Guru dan Dosen (UUGD) menyebutkan bahwa kompetensi guru meliputi kompetensi pendagogik, kompetensi kepribadian, kompetensi sosial, dan kompetensi profesional.

Diantara empat kompetensi yang harus dimiliki oleh seorang guru, peneliti hanya membatasi kompetensi profesional yang dinilai mempunyai pengaruh cukup erat dengan etos kerja guru. Kompetensi profesional merupakan penguasaan materi pembelajaran secara luas dan mendalam, yang mencakup penguasaan materi kurikulum mata pelajaran di sekolah dan substansi keilmuan yang menaungi materinya, serta penguasaan terhadap stuktur dan metodologi keilmuannya. Teori yang menunjukkan adanya keterkaitan antara kompetensi dengan kinerja guru yang diharapkan dapat meningkatkan mutu pendidikan ini merujuk kepada pendapat
Robbins (2001:173) pada bagian terdahulu telah dikemukakan bahwa kinerja merupakan fungsi interaksi antara kemampuan atau ability (A), motivasi atau motivation (M) dan kesempatan atau opportunity $(\mathrm{O})$ yang dapat dinyatakan dalam formula kinerja $=f(A \times M \times O)$.

Sekolah merupakan lembaga yang terorganisasi oleh karena itu sekolah tidak bisa lepas dari yang namanya komunikasi, karena komunikasi merupakan bagian internal dari organisasi. Komunikasi ibarat system yang menghubungkan antar orang, antar bagian dalam organisasi. Efektivitas organisasi terletak pada efektivitas komunikasi, sebab komunikasi itu penting untuk menghasilkan pemahaman yang sama antara pengirim informasi dengan penerima informasi pada semua anggota dan pemimpin dalam organisasi. Selain itu komunikasi juga berperan untuk membangun organisasi yang pada akhirnya dapat mempengaruhi efisiensi dan produktivitas organisasi guna mencapai suatu tujuan organisasi tersebut.

Dalam melakukan kegiatan organisasi, komunikasi memegang peran yang sangat penting, karena dengan adanya komunikasi, organisasi dapat mengarahkan, mengkoordinir dan 
mengawasi kegiatan anggotanya dalam mencapai tujuan organisasi. Hal ini sesuai dengan pendapat yang dikemukakan Arni Muhammad (2000:1) bahwa "Organisasi adalah suatu sistem hubungan yang terstruktur dan yang mengkoordinir usaha sekelompok orang untuk mencapai tujuan, juga memerlukan komunikasi yaitu komunikasi organisasi".

Tanpa adanya komunikasi organisasi di dalam suatu organisasi maka tujuan organisasi tidak mungkin akan dicapa dan bila komunikasi organisasi tidak berjalan sebagaimana mestinya maka semua informasi yang dibutuhkan oleh setiap anggota di dalam organisasi tentu tidak akan sampai. Seperti yang dikemukakan oleh Ami, Katz dan Kahn (Miftah Toha, 2003:181) bahwa "komunikasi adalah proses sosial yang mempunyai relevansi terluas di dalam memfungsikan setiap kelompok, organisasi dan masyarakat". Oleh sebab itu, komunikasi harus berlangsung terus menerus, bila tujuan organisasi hendak dicapai dengan efisien.

Disamping itu komunikasi organisasi merupakan suatu sistem yang saling bergantung dengan komponen organisasi, seperti yang dikemukakan oleh Zelko dan Dance (Arni Muhammad, 2000:67) yaitu "Komunikasi organisasi adalah suatu sistem yang bergantung yang mencakup komunikasi internal dan komunikasi eksternal". Komunikasi internal merupakan komunikasi yang berlangsung di dalam organisasi itu sendiri, misalnya komunikasi yang datang dari atasan kepada bawahan, atau sebaliknya dari bawahan kepada atasan dan juga komunikasi antar pegawai yang sama tingkatannya. Sedangkan komunikasi eksternal adalah komunikasi yang dilakukan oleh organisasi terhadap lingkungan luar seperti, hubungan dengan organisasi lain atau dengan masyarakat luas.

Dalam organisasi apapun komunikasi merupakan alat yang berfungsi sebagai sumber informasi yang sangat bermanfaat bagi para pemimpin di dalam melakukan tugas-tugas kepemimpinannya. Dengan kemampuan berkomunikasi seorang pemimpin dapat meningkatkan kualitas pelaksanaan tugas atau peran utama dalam menggerakkan sumber daya manusia dan sumber daya lainnya dalam aktivitas dan evektifitas organisasi.

Kualitas lulusan tergantung dari kulitas keterlaksanaan proses belajar mengajar ( PBM), PBM yang berkulitas dan baik akan terwujud jika guru (pendidik) melaksanakan ide, konsep atau nilai-nilai yang terkandung dalam 
kurikulum dalam aktivitas pembelajaran dikelas. Sebagaimana dikemukakan Nana Sudjana (2004:67) bahwa, proses belajar mengajar merupakan sebuah proses penterjemahan dan pentransformasian nilai- nilai yang terkandung dalam kurikulum. Hal ini menunjukkan bahwa ketercapaian kurikulum tergambarkan pada mutu keterlaksanaan PBM.

Guru merupakan unsur yang sangat dominan dan sangat strategis didalam proses belajar mengajar. Suharsimi Arikunto (2006 :217) mengemukakan bahwa " guru merupakan unsur yang mempunyai peran amat penting bagi terwujudnya pembelajaran, menurut kualitas yang dikendaki”. Oleh karena itu diperlukan adanya pengembangan profesionalisme guru.

Pengembangan profesionalisme guru menjadi perhatian secara global, karena guru memiliki tugas dan peran bukan hanya memberikan informasiinformasi ilmu pengetahuan dan teknologi, melainkan juga membentuk sikap dan jiwa yang mampu bertahan dalam era hiperkompetensi. Kebutuhan untuk mengembangkan diri (self actualization) merupakan kebutuhan yang paling tinggi bagi setiap orang. Realisasi pengembangan diri ini berbagai macam bentuknya, antara lain melalui pendidikan yang lebih tinggi atau pelatihan-pelatihan peningkatan kemampuan. Di sekolah, kesempatan untuk meningkatkan kemampuan melalui pendidikan atau pelatihan, baik bergelar maupun non gelar merupakan usaha untuk memberikan kesempatan bagi guru-guru guna memenuhi kebutuhan. Tugas guru adalah membantu peserta didik agar mampu melakukan adaptasi terhadap berbagai tantangan kehidupan serta desakan yang berkembang dalam dirinya.

Berdasarkan uraiaan di atas, penulis berasumsi bahwa masalah etos kerja guru dapat dipengaruhi oleh faktorfaktor eksternal dan internal. Mengingat terlalu banyaknya faktor yang mempengaruhi etos kerja guru, maka dalam penelitian ini penulisan memfokuskan pada faktor komunikasi organisasi dan pengembangan guru. Beranjak dari asumsi tersebut penulis mencoba menggali lebih dalam lagi adakah kontribusi efektif dan tidaknya komunikasi organisasi dan pengembangan guru terhadap etos kerja guru? Untuk menjawab hal tersebut diperlukan pembuktian secara empirik di lapangan.

Berdasarkan hasil pengamatan di lapangan yang penulis amati di Sekolah 
Menengah Pertama (SMP) negeri di Kecamatan Jatibarang Kabupaten Indramayu, ditemukan beberapa fenomena mengenai etos kerja guru diantaranya: (1) Masih sekitar $30 \%$ guru datang terlambat ke sesolah atau tidak taat aturan sekolah. (2) sekitar $25 \%$ guru masih bersaing dengan rekan guru menggunakan cara-cara yang kurang sehat. (3). Diperkirakan $25 \%$ guru masih mengedepankan kepentingan dirinya dibandingkan kepentingan sekolah. (4). Diperkirakan sekitar $25 \%$ masih ada guru belum mengedepankan tugas sebagai gurunya. (5).Masih sekitar $30 \%$ guru enggan bekerja pada waktu liburan seperti pada waktu pelaksanaan penerimaan siswa baru (6). Diperkirakan sekitar $15 \%$ masih ada guru yang belum menyadari bahwa profesi guru merupakan rahmat. (7). Diperkirakan sekitar $15 \%$ masih ada guru yang belum menyadari bahwa profesi guru merupakan panggilan dalam mencerdaskan kehidupan bangsa. (8). Diperkirakan sekitar $10 \%$ masih ada guru yang belum menyadari bahwa profesi guru merupakan ibadah. Berdasarakan latar belakang masalah di atas maka dalam penelitian ini penulis mengambil judul: "Pengaruh Komunikasi Organisasi dan Pengembangan Guru terhadap Etos Kerja Guru (Studi
Deskriptif Analitik pada Guru SMP Negeri di Sektor 3 Kecamatan Jatibarang Kabupaten Indramayu)".

Nawawi (2002:15) mengelompokkan ruang lingkup administrasi pendidikan kedalam dua bidang yakni manajemen administratif dan manajemen operasional. manajemen administratif merupakan upaya untuk mengarahkan semua yang terlibat dalam organisasi atau kelompok kerjasama untuk mengerjakan hal-hal yang tepat sesuai dengan tujuan yang ingin dicapai. Beberapa kegiatan yang termasuk manajemen administratif, meliputi (1) perencanaan, (2) organisasi, (3) bimbingan, (4) pengarahan, (5) koordinasi, (6) pengawasan serta (7) komunikasi. Manajemen operasional bertujuan untuk membina dan mengarahkan agar pekerjaan yang menjadi beban tugas masing-masing dilaksanakan dengan tepat dan benar. Kegiatan manajemen operasional meliputi: (1) tata usaha, (2) perbekalan (3) kepegawaian, (4) keuangan, dan (5) hubungan masyarakat.

Supandi dan Sanusi (2000:116) mengungkapkan bahwa bidang garapan manajemen pendidikan meliputi: (1) organisasi kurikulum, (2) perlengkapan pendidikan, (3) media pendidikan, (4) 
personil, (5) hubungan kemanusiaan dan (6) dana finansial atau keuangan.

Tasmara

$(2002: 15)$

mengemukakan bahwa kata etos berasal dari bahasa Yunani (ethos) yang memberikan arti sikap, watak, karakter serta keyakinan atas sesuatu. Sedangkan dalam istilah Inggris ethos diartikan sebagai watak atau semangat fundamental suatu budaya, berbagai ungkapan yang menunjukkan kepercayaan, kebiasaan, atau perilaku suatu kelompok masyarakat.

Tasmara (2002:15) memaparkan bahwa dalam etos ada semacam semangat untuk menyempurnakan segala sesuatu dan menghindari segala kerusakan sehingga setiap pekerjaannya diarahkan untuk mengurangi bahkan menghilangkan sama sekali cacat dari hasil kerjanya.

Ndraha (2002:91) bahwa etos kerja berkaitan erat dengan budaya kerja, sehingga akan menghasilkan produktivitas dan kualitas kerja. Suatu pekerjaan akan lebih terasa ringan apabila dikerjakan dengan semangat yang kuat demi memehuhi tanggung jawab kerja yang diemban. Begitu pula dengan guru, apabila hanya berorientasi pada suatu bentuk usaha komersial maka meraka akan cenderung mengajar dengan seenaknya tanpa memperhatikan apa yang diperolehpeserta didiknya dari pembelajaran yang berlangsung.

Djohar MS (2006:125) etos kerja guru sebagai perwujudan memanage diri sendiri yang kreatif terukur dari kinerja guru, tahu apa yang dikerjakan, mampu menciptakan kerja tanpa perintah orang lain, segera beralih kepekerjaan lain bila telah selesai, mampu mengatur waktu dan menikmati pekerjaan. Melalui etos kerja guru semakin memiliki rasa tanggung jawab terhadap profesinya, sehingga guru akan mengoptimakan pencapaian standar kerja guru salah satunya satndar kompetensi professional guru.

Anoraga (2006:29) Etos Kerja merupakan suatu pandangan dan sikap suatu bangsa atau umat terhadap kerja. Bila individu-individu dalam komunitas memandang kerja sebagai suatu hal yang luhur bagi eksistensi manusia, maka etos kerjanya akan cenderung tinggi. Sebaliknya sikap dan pandangan terhadap kerja sebagai sesuatu yang bernilai rendah bagi kehidupan, maka Etos Kerja dengan sendirinya akan rendah.

Mulyana (2010:23) bahwa sebagai guru etos kerja itu sangat penting, karena 
sebesar apapun etos kerja sangat menentukan produktivitas yang akan dihasilkan. Kompetensi profesional mengharuskan guru untuk terus mengembangkan pengetahuannya serta mampu mengelola pembelajaran oleh karena itu etos kerja diperlukan agar guru lebih produktif dalam menjalankan tugasnya.

Sinamo (2008:26), Etos Kerja profesional adalah seperangkat perilaku positif yang berakar pada keyakinan fundamental yang disertai komitmen total pada paradigma kerja yang integral.

Melalui berbagai pengertian diatas dapat disimpulkan bahwa Etos Kerja merupakan seperangkat sikap atau pandangan mendasar yang dipegang seseorang agar dapat meningkatan kualitas kehidupan sehingga mempengaruhi perilaku kerjanya.

Everest Rogers dan Shocmaker dikutip oleh F. Rahmadi (2005:36) bahwa "Komunikasi sebagai suatu cara penyampaian pesan dari sumber ke penerima pesan".

Raymond E. Miles dikutip oleh Djs Reusub Cardoso Gomes (2005:12) mencoba memberikan batasan mengenai organisasi sebagai berikut"... organisasi tidak lebih dari pada sekelompok orang yang berkumpul bersama di sekitar suatu tekhnologi yang dipergunakan untuk mengubah input-input dari lingkungan barang/jasa-jasa yang dipaksakan”.

Pendapat Goldhaber yang dikutip oleh Arni Muhammad (2000:10) yaitu: Organizational comunication is the processofcreating and exhanging within a network of interdependent relation ship of cope whith environmental uncertainly. Berdasar kutipan di atas dapat dikemukakan bahwa komunikasi organisasi adalah proses menciptakan dan saling menukar pesan dalam satu jaringan hubungan yang saling tergantung satu sama yang lain untuk mengatasi lingkungan yang tidak pasti atau yang selalu berubah-ubah.

Reading dan Sanbron, dikutip oleh Arni Muhammad (2000:12) mengemukakan bahwa "Komunikasi organisasi adalah pengiriman dan penerimaan informasi dalam organisasi yang komplek". Lebih lanjut Arni Muhammad mengutip pendapat Kate dan Kahn yang mengatakan bahwa, "Komunikasi Organisasi merupakan arus informasi, pertukaran informasi dan pemindahan (meaning) atau arti di dalam suatu organisasi”. 
Dari beberapa definisi komunikasi organisasi yang dikemukakan para ahli di atas dapat disimpulkan bahwa komunikasi organisasi merupakan suatu proses penyampaian dan penerimaan (pertukaran) pesan atau informasi dalam suatu organisasi yang berkenaan dengan tugas-tugas dalam organisasi demi kelanjutan jalannya organisasi untuk mencapai suatu tujuan.

$\begin{array}{ccc}\text { Suharsimi } & \text { Arikunto (2006:217) } \\ \text { mengemukakan } & \text { bahwa “ guru }\end{array}$
merupakan unsur yang mempunyai peran amat penting bagi terwujudnya pembelajaran, menurut kualitas yang dikendaki”.

\section{Zamroni (2000:29) bahwa} "guru merupakan sumber ilmu dan ketrampilan, dimana kehadirannya dimuka kelas merupakan kondisi mutlak yang harus ada agar proses belajar mengajar berlangsung".

Kunandar (2007:46) menjelaskan bahwa guru yang profesional adalah guru yang memiliki kompetensi yang dipersyaratkan untuk melakukan tugas pendidikan dan pengajaran. Kompetensi disini meliputi pengetahuan, sikap dan keterampilan profesional, baik yang bersifat pribadi, sosial maupun akademis. Dengan kata lain pengertian guru profesional adalah orang yang memiliki kemampuan dan keahlian khusus dalam bidang keguruan sehingga ia mampu melakukan tugas dan fungsinya sebagai guru dan dengan kemampuan maksimal. Jadi guru yang profesional adalah orang yang terdidik dan erlatih dengan baik, serta memiliki pengalaman dibidangnya.

Surya dalam Kunardar (2007:47) menjelaskan bahwa guru yang profesional akan tercermin dalam pelaksanaan pengabdian tugas-tugas yang ditandai dengan keahlian baik dalam materi maupun metode. Selain itu, juga ditunjukkan dengan tanggung jawabnya dalam melaksanakan seluruh pengabdiannya. Guru yang profesional hendaknya mampu memikul dan melaksanakan tanggung jawab sebagai guru kepada peserta didik, orang tua, masyarakat, bangsa, negara, dan agamanya.

Mulyasa ( 2003:43) menyebutkan bahwa pengembangan guru dapat dilakukan dengan cara on the job training dan in service training.

\section{METODE PENELITIAN}

- Metode penelitian yang digunakan dalam penelitian ini adalah metode deskriptif dengan pendekatan kuantitatif. Metode penelitian deskriptif yaitu metode yang digunakan dalam penelitian untuk 
menganalisis peristiwa-peristiwa yang terjadi pada saat penelitian berlangsung. Sedangkan yang dimaksud dengan pendekatan kuantitatif merupakan pendekatan yang digunakan dalam penelitan dengan cara mengukur indikator-indikator variabel penelitian sehingga diperoleh gambaran konstribusi variabel bebas terhadap variabel terikat.

Populasi dalam penelitian ini adalah guru SMPN mata pelajaran di sektor 3 Kecamatan Jatibarang Kabupaten Indramayu yang berjumlah 320 orang.

Dalam penelitian ini sampel yang diambil adalah guru-guru SMPN mata pelajaran

Tabel 1

Signifikansi Pengaruh Variabel $\mathrm{X}_{1}$ terhadap Y

\begin{tabular}{|c|c|c|c|c|c|c|}
\hline Model & & $\begin{array}{l}\text { Sum of } \\
\text { Squares }\end{array}$ & $d f$ & $\begin{array}{c}\text { Mean } \\
\text { Square }\end{array}$ & $F$ & Sig. \\
\hline 1 & $\begin{array}{l}\text { Regression } \\
\text { Residual } \\
\text { Total }\end{array}$ & $\begin{array}{r}223,278 \\
1038,231 \\
1261,509\end{array}$ & $\begin{array}{r}2 \\
67 \\
69\end{array}$ & $\begin{array}{r}223,278 \\
20,33\end{array}$ & 11,983 &, $002^{b}$ \\
\hline
\end{tabular}

Besar pengaruh komunikasi organisasi terhadap etos kerja guru dari hasil perhitungan koefesien determinasi adalah bahwa $R$ Square sebesar 0,220, hal ini berarti bahwa $22 \%$ etos kerja guru dipengaruhi oleh variabel komunikasi organisasi, sedangkan sisanya $78 \%$ di sektor 3 Kecamatan Jatibarang Kabupaten Indramayu, dengan jumlah sampel 80 guru.

\section{HASIL DAN PEMBAHASAN \\ Pengaruh Komunikasi Organisasi terhadap Etos Kerja Guru}

Berdasarkan tabel hasil uji anova atau $\mathrm{F}$ test didapat $F_{\text {hitung }}$ sebesar 11,983 dan nilai signifikansi $0,02<0,05$. Seperti tampil pada tabel 1. Dengan demikian $\mathrm{H}_{\mathrm{o}}$ ditolak artinya pengaruh komunikasi organisasi terhadap etos kerja guru SMP Negeri di Sektor 3 Kecamatan Jatibarang Kabupaten Indramayu adalah signifikan. 
sehingga $\mathrm{H}_{\mathrm{o}}$ ditolak artinya pengaruh pengembangan guru terhadap etos kerja guru SMP Negeri di Sektor 3 Kecamatan
Jatibarang Kabupaten Indramayu adalah signifikan.

Tabel 2

Signifikansi Variabel $\mathrm{X}_{2}$ terhadap Y

\begin{tabular}{|rl|r|r|r|r|r|}
\hline Model & & Sum of Squares & Df & Mean Square & F & Sig. \\
\hline 1 & Regression & 436,092 & 1 & 436,092 & 26,276 &, $000^{\mathrm{b}}$ \\
& Residual & 946,010 & 68 & 16,597 & & \\
& 1382,102 & 69 & & & \\
\hline
\end{tabular}

Besar pengaruh pengembangan guru terhadap etos kerja guru dapat dilihat dari hasil perhitungan koefesien determinasi bahwa $R$ Square sebesar 0,361, hal ini berarti bahwa $36,1 \%$ etos kerja guru dipengaruhi oleh variabel pengembangan guru, sedangkan sisanya $63,9 \%$ dipengaruhi oleh faktor lain yang tidak diteliti.

Pengaruh Komunikasi Organisasi dan

Pengembangan Guru Secara Simultan

Terhadap Etos Kerja Guru
Berdasarkan tabel 3 hasil uji anova atau F test didapat $F_{\text {hitung }}$ sebesar 12,394 dan signifikansi $0,029<0,05$ sehingga $\mathrm{H}_{\mathrm{o}}$ ditolak artinya pengaruh komunikasi organisasi dan pengembangan guru secara simultan terhadap etos kerja guru SMP Negeri di Sektor 3 Kecamatan Jatibarang Kabupaten Indramayu adalah signifikan.

Tabel 3

Signifikansi Variabel $\mathrm{X}_{1}, \mathrm{X}_{2}$ terhadap $\mathrm{Y}$

\begin{tabular}{|l|r|r|r|r|r|}
\hline Model & \multicolumn{1}{c|}{$\begin{array}{c}\text { Sum of } \\
\text { Squares }\end{array}$} & Df & $\begin{array}{c}\text { Mean } \\
\text { Square }\end{array}$ & F & Sig. \\
\hline 1 Regression & 639,199 & 2 & 319,599 & 12,394 &, $029^{\mathrm{b}}$ \\
Residual & 8943,251 & 67 & 133,481 & & \\
Total & 9582,450 & 69 & & & \\
\hline
\end{tabular}

Besar pengaruh komunikasi organisasi dan pengembangan guru secara simultan terhadap etos kerja guru dari hasil perhitungan koefesien determinasi bahwa
$R$ Square sebesar 0,367, hal ini berarti bahwa $36,7 \%$ etos kerja guru dipengaruhi oleh variabel komunikasi organisasi dan pengembangan guru secara simultan, 
sedangkan sisanya $63,3 \%$ dipengaruhi faktor lain yang tidak diteliti.

Permasalahan yang ingin dijawab dalam penelitian ini adalah pertama, pengaruh pelaksanaan komunikasi organisasi terhadap etos kerja guru SMP Negeri di Sektor 3 Kecamatan Jatibarang Kabupaten Indramayu. Secara empirik, hasil penelitian ini menginformasikan: (1) terdapat pengaruh yang signifikan komunikasi organisasi terhadap etos kerja guru SMP di Sektor 3 Kecamatan Jatibarang Kabupaten Indramayu, serta (2) besarnya pengaruh komunikasi organisasi terhadap etos kerja guru SMP Negeri di Sektor 3 Kecamatan Jatibarang Kabupaten Indramayu ditunjukkan oleh hasil penelitian bahwa komunikasi organisasi yang terdiri dari dimensi: (1) "Downward communication" atau komunikasi kepada bawahan; "Upward communication" atau komunikasi kepada atasan;

"Horizontal communication" atau komunikasi horizontal. Pendapat Muhammad (2000:108), membawa implikasi yang signifikan terhadap etos kerja guru yang meliputi dimensi: (1) menjadi guru adalah rahmat; (2) menjadi guru adalah amanah; (3) menjadi guru adalah pangilan; (4) menjadi guru adalah aktualisasi; (5) menjadi guru adalah ibadah (6) menjadi guru adalah seni; (7) menjadi guru adalah kehormatan; dan (8) menjadi guru adalah pelayanan (Sinamo, 2008:20). Namun demikian etos kerja guru pada SMP Negeri di Sektor 3 Kecamatan Jatibarang Kabupaten Indramayu ini tidak hanya dipengaruhi oleh komunikasi organisasisaja, ada faktor lain (epsilon), selain motivasi kepala sekolah, yang juga berpengaruh, yang tidak dikaji dalam penelitian ini.

Dengan demikian, hasil penelitian ini mengindikasikan bahwa semakin bagus komunikasi organisasi yang dilaksanakan SMP Negeri di Sektor 3 Kecamatan Jatibarang Kabupaten Indramayu, maka akan diikuti oleh semakin tingginya etos kerja guru. Hal ini dapat diterangkan oleh persamaan regresi $\mathrm{Y}=53,355+0,163 \mathrm{X}_{1}$. Dengan persamaan regresi tersebut dapat diinterpretasikan bahwa jika komunikasi organisasi $\left(\mathrm{X}_{1}\right)$ dan etos kerja guru $(\mathrm{Y})$ diukur dengan instrumen yang dikembangkan dalam penelitian ini, maka setiap perubahan skor komunikasi organisasi sebesar satu satuan dapat diestimasikan skor etos kerja guru akan berubah 0,163 satuan pada arah yang sama.

Berdasarkan temuan empirik yang menunjukkan adanya pengaruh yang 
signifikan komunikasi organisasi terhadap etos kerja guru, maka hasil penelitian ini memberikan beberapa informasi, di antaranya: (1) Pelaksanaan komunikasi organisasi pada SMP Negeri di Sektor 3 Kecamatan Jatibarang Kabupaten Indramayu memberikan pengaruh yang berarti terhadap etos kerja guru, (2) Salah satu cara untuk meningkatkan etos kerja guru negeri SMP Negeri di Sektor 3 Kecamatan Jatibarang Kabupaten Indramayu adalah dengan meningkatkan pelaksanaan komunikasi organisasi, serta

Kontribusi yang diberikan oleh pengaruh komunikasi organisasi terhadap etos kerja guru negeri SMP Negeri di Sektor 3 Kecamatan Jatibarang Kabupaten Indramayu adalah sebesar 22\%, sementara sisanya dipengaruhi oleh variabel lain, yang tidak dikaji dalam penelitian ini (epsilon).

Kedua, adakah pengaruh pengembangan guru terhadap etos kerja guru negeri SMP Negeri di Sektor 3 Kecamatan Jatibarang Kabupaten Indramayu. Secara empirik, hasil penelitian ini menginformasikan: (1) terdapat pengaruh yang signifikan pengembangan guru terhadap etos kerja guru negeri SMP Negeri di Sektor 3 Kecamatan Jatibarang Kabupaten
Indramayu, serta (2) besarnya pengaruh pengembangan guru terhadap etos kerja guru negeri SMP Negeri di Sektor 3 Kecamatan Jatibarang Kabupaten Indramayu ditunjukkan oleh hasil penelitian bahwa tingginya pengembangan guru yang terdiri dari dimensi: : Individual guided staff development (pengembangan guru yang dipadu secara individual), Observation/Assessment (observasi atau penilaian), (3) Involvement in a development/ improvement process (keterlibatan dalam suatu proses pengembangan/peningkatan, (4) Training (pelatihan), (5) Inquiry (pemeriksaan) (Castetter dalam Syaefuddin, 2010:102), membawa implikasi yang signifikan terhadap etos kerja guru yang meliputi dimensi: (1) menjadi guru adalah rahmat; (2) menjadi guru adalah amanah; (3) menjadi guru adalah pangilan; (4) menjadi guru adalah aktualisasi; (5) menjadi guru adalah ibadah (6) menjadi guru adalah seni; (7) menjadi guru adalah kehormatan; dan (8) menjadi guru adalah pelayanan (Sinamo, 2008:20). Namun demikian etos kerja guru SMP Negeri di Sektor 3 Kecamatan Jatibarang Kabupaten Indramayu ini tidak hanya dipengaruhi oleh pengembangan guru saja, ada faktor lain (epsilon), selain komunikasi organisasi yang juga berpengaruh, yang 
tidak dikaji dalam penelitian ini.

Dengan demikian, hasil penelitian ini mengindikasikan bahwa semakin tinggi (bagus) pengembangan guru guru SMP Negeri di Sektor 3 Kecamatan Jatibarang Kabupaten Indramayu, maka akan diikuti oleh semakin tingginya etos kerja guru. Hal ini dapat diterangkan oleh persamaan regresi $\mathrm{Y}=70,375+$ $0,790 X_{2}$. Dengan persamaan regresi tersebut dapat diinterpretasikan bahwa jika pengembangan guru $\left(\mathrm{X}_{2}\right)$ dan etos kerja guru (Y) diukur dengan instrumen yang dikembangkan dalam penelitian ini, maka setiap perubahan skor pengembangan guru sebesar satu satuan dapat diestimasikan skor etos kerja guru akan berubah 0,790 satuan pada arah yang sama.

Berdasarkan temuan empirik yang menunjukkan adanya pengaruh yang signifikan pengembangan guru terhadap etos kerja guru, maka hasil penelitian ini memberikan beberapa informasi, di antaranya: (1) Pengembangan guru SMP Negeri di Sektor 3 Kecamatan Jatibarang Kabupaten Indramayu memberikan pengaruh yang berarti terhadap etos kerja guru, (2) Salah satu cara untuk meningkatkan etos kerja guru SMP Negeri di Sektor 3 Kecamatan Jatibarang Kabupaten Indramayu adalah dengan meningkatkan pengembangan guru, serta
(3) Kontribusi yang diberikan oleh pengaruh pengembangan guru terhadap etos kerja guru adalah sebesar 36,1\%, sementara sisanya dipengaruhi oleh variabel lain, selain variabel komunikasi organisasi, yang tidak dikaji dalam penelitian ini (epsilon).

Ketiga, adakah pengaruh komunikasi organisasi dan pengembangan guru secara simultan terhadap etos kerja guru SMP Negeri di Sektor 3 Kecamatan Jatibarang Kabupaten Indramayu. Secara empirik, hasil penelitian ini menginformasikan: (1) terdapat pengaruh yang signifikan komunikasi organisasi dan pengembangan guru secara simultan terhadap etos kerja guru SMP Negeri di Sektor 3 Kecamatan Jatibarang Kabupaten Indramayu, serta (2) besarnya pengaruh komunikasi organisasi dan pengembangan guru secara simultan terhadap etos kerja guru negeri SMP di Sektor 3 Kecamatan Jatibarang Kabupaten Indramayu ditunjukkan oleh hasil penelitian bahwa komunikasi organisasi yang terdiri dari dimensi: (1) "Downward communication" atau komunikasi kepada bawahan; (2) "Upward communication" atau komunikasi kepada atasan; (3) "Horizontal communication" atau komunikasi horizontal. Pendapat Muhammad (2000:108), serta pengembangan guru yang terdiri dari dimensi: (1) Individual guided 
staff development (pengembangan guru yang dipadu secara individual), (2) Observation/Assessment (observasi atau penilaian), (3) Involvement in a development/improvement process (keterlibatan dalam suatu proses pengembangan/peningkatan, (4) Training (pelatihan), (5) Inquiry (pemeriksaan) (Castetter dalam Syaefudin, 2010:102), membawa implikasi yang signifikan terhadap etos kerja guru yang meliputi dimensi: (1) menjadi guru adalah rahmat; (2) menjadi guru adalah amanah; (3) menjadi guru adalah pangilan; (4) menjadi guru adalah aktualisasi; (5) menjadi guru adalah ibadah (6) menjadi guru adalah seni; (7) menjadi guru adalah kehormatan; dan (8) menjadi guru adalah pelayanan (Sinamo, 2008:20). Namun demikian etos kerja guru SMP Negeri di Sektor 3 Kecamatan Jatibarang Kabupaten Indramayu, tidak hanya dipengaruhi oleh komunikasi organisasi dan pengembangan guru guru saja, ada faktor lain (epsilon), yang juga berpengaruh, yang tidak dikaji dalam penelitian ini.

\section{Menurut Sinungan (2005:64)} yang mengemukakan bahwa: 2 kelompok besar faktor-faktor yang mempengaruhi produktivitas, yang masing-masing faktor tersebut berlaku dalam cara yang berbeda dan dengan pengaruh yang berbeda dan dalam keadaan yang berbeda pula. Faktor yang dimaksud yaitu: (1) Kelompok kesatu: tingkat pendidikan dan keahlian, jenis teknologi dan hasil produksi, kondisi kerja, kesehatan, kemampuan fisik dan mental. (2) Kelompok kedua mencakup: Sikap (terhadap tugas), teman sejawat dan pengawas, keanekaragaman tugas,. sistem insentif, kepuasan kerja, kepastian pekerjaan, perspekrif dari ambisi dan promosi.

Dengan demikian, hasil penelitian ini mengindikasikan bahwa semakin bagus komunikasi organisasi dan pengembangan guru secara simultan pada SMP Negeri di Sektor 3 Kecamatan Jatibarang Kabupaten Indramayu, maka akan diikuti oleh semakin tingginya etos kerja guru. Hal ini dapat diterangkan oleh persamaan regresi $\hat{Y}=58,684+0,343 X_{1}$ $+0,268 X_{2}$. Dengan persamaan regresi tersebut dapat diinterpretasikan bahwa jika komunikasi organisasi $\left(\mathrm{X}_{1}\right)$, dan pengembangan guru $\left(\mathrm{X}_{2}\right)$ serta etos kerja guru (Y) diukur dengan instrumen yang dikembangkan dalam penelitian ini, maka setiap perubahan skor pelaksanaan komunikasi organisasi, dan pengembangan guru secara simultan sebesar satu satuan dapat diestimasikan skor etos kerja guru akan berubah 0,343 dan 0,268 satuan pada arah yang sama. 
Berdasarkan temuan empirik yang menunjukkan adanya pengaruh yang signifikan komunikasi organisasi dan pengembangan guru terhadap etos kerja guru, maka hasil penelitian ini memberikan beberapa informasi, di antaranya: (1) Pelaksanaan komunikasi organisasi dan pengembangan guru pada SMP Negeri di Sektor 3 Kecamatan Jatibarang Kabupaten Indramayu memberikan pengaruh yang berarti terhadap etos kerja guru SMP Negeri di Sektor 3 Kecamatan Jatibarang Kabupaten Indramayu, (2) Salah satu cara untuk meningkatkan etos kerja guru SMP Negeri di Sektor 3 Kecamatan Jatibarang Kabupaten Indramayu adalah dengan meningkatkan komunikasi organisasi dan pengembangan guru. (3) Kontribusi yang diberikan oleh komunikasi organisasi dan pengembangan guru secara bersamasama terhadap etos kerja guru SMP Negeri di Sektor 3 Kecamatan Jatibarang Kabupaten Indramayu adalah sebesar $36,7 \%$, sementara sisanya dipengaruhi oleh variabel lain, yang tidak dikaji dalam penelitian ini (epsilon).

Permasalahan yang ingin dijawab dalam penelitian ini adalah pertama, pengaruh pelaksanaan komunikasi organisasi terhadap etos kerja guru SMP Negeri di Sektor 3 Kecamatan Jatibarang
Kabupaten Indramayu. Secara empirik, hasil penelitian ini menginformasikan: (1) terdapat pengaruh yang signifikan komunikasi organisasi terhadap etos kerja guru SMP di Sektor 3 Kecamatan Jatibarang Kabupaten Indramayu, serta (2) besarnya pengaruh komunikasi organisasi terhadap etos kerja guru SMP Negeri di Sektor 3 Kecamatan Jatibarang Kabupaten Indramayu ditunjukkan oleh hasil penelitian bahwa komunikasi organisasi yang terdiri dari dimensi: (1) "Downward communication" atau komunikasi kepada bawahan; "Upward communication" atau komunikasi kepada atasan; (3) "Horizontal communication" atau komunikasi horizontal. Pendapat Muhammad (2000:108), membawa implikasi yang signifikan terhadap etos kerja guru yang meliputi dimensi: (1) menjadi guru adalah rahmat; (2) menjadi guru adalah amanah; (3) menjadi guru adalah pangilan; (4) menjadi guru adalah aktualisasi; (5) menjadi guru adalah ibadah (6) menjadi guru adalah seni; (7) menjadi guru adalah kehormatan; dan (8) menjadi guru adalah pelayanan (Sinamo, 2008:20). Namun demikian etos kerja guru pada SMP Negeri di Sektor 3 Kecamatan Jatibarang Kabupaten Indramayu ini tidak hanya dipengaruhi oleh komunikasi 
organisasisaja, ada faktor lain (epsilon), selain motivasi kepala sekolah, yang juga berpengaruh, yang tidak dikaji dalam penelitian ini.

Dengan demikian, hasil penelitian ini mengindikasikan bahwa semakin bagus komunikasi organisasi yang dilaksanakan SMP Negeri di Sektor 3 Kecamatan Jatibarang Kabupaten Indramayu, maka akan diikuti oleh semakin tingginya etos kerja guru. Hal ini dapat diterangkan oleh persamaan regresi $\mathrm{Y}=53,355+0,163 \mathrm{X}_{1}$. Dengan persamaan regresi tersebut dapat diinterpretasikan bahwa jika komunikasi organisasi $\left(\mathrm{X}_{1}\right)$ dan etos kerja guru $(\mathrm{Y})$ diukur dengan instrumen yang dikembangkan dalam penelitian ini, maka setiap perubahan skor komunikasi organisasi sebesar satu satuan dapat diestimasikan skor etos kerja guru akan berubah 0,163 satuan pada arah yang sama.

Berdasarkan temuan empirik yang menunjukkan adanya pengaruh yang signifikan komunikasi organisasi terhadap etos kerja guru, maka hasil penelitian ini memberikan beberapa informasi, di antaranya: (1) Pelaksanaan komunikasi organisasi pada SMP Negeri di Sektor 3 Kecamatan Jatibarang Kabupaten Indramayu memberikan pengaruh yang berarti terhadap etos kerja guru, (2) Salah satu cara untuk meningkatkan etos kerja guru negeri SMP Negeri di Sektor 3 Kecamatan Jatibarang Kabupaten Indramayu adalah dengan meningkatkan pelaksanaan komunikasi organisasi, serta

Kontribusi yang diberikan oleh pengaruh komunikasi organisasi terhadap etos kerja guru negeri SMP Negeri di Sektor 3 Kecamatan Jatibarang Kabupaten Indramayu adalah sebesar 22\%, sementara sisanya dipengaruhi oleh variabel lain, yang tidak dikaji dalam penelitian ini (epsilon).

Kedua, adakah pengaruh pengembangan guru terhadap etos kerja guru negeri SMP Negeri di Sektor 3 Kecamatan Jatibarang Kabupaten Indramayu. Secara empirik, hasil penelitian ini menginformasikan: (1) terdapat pengaruh yang signifikan pengembangan guru terhadap etos kerja guru negeri SMP Negeri di Sektor 3 Kecamatan Jatibarang Kabupaten Indramayu, serta (2) besarnya pengaruh pengembangan guru terhadap etos kerja guru negeri SMP Negeri di Sektor 3 Kecamatan Jatibarang Kabupaten Indramayu ditunjukkan oleh hasil penelitian bahwa tingginya pengembangan guru yang terdiri dari dimensi: : Individual guided staff 
development (pengembangan guru yang

dipadu secara individual),

Observation/Assessment (observasi atau penilaian), (3) Involvement in a development/ improvement process (keterlibatan dalam suatu proses pengembangan/peningkatan, (4) Training (pelatihan), (5) Inquiry (pemeriksaan) (Castetter dalam Syaefuddin, 2010:102), membawa implikasi yang signifikan terhadap etos kerja guru yang meliputi dimensi: (1) menjadi guru adalah rahmat; (2) menjadi guru adalah amanah; (3) menjadi guru adalah pangilan; (4) menjadi guru adalah aktualisasi; (5) menjadi guru adalah ibadah (6) menjadi guru adalah seni; (7) menjadi guru adalah kehormatan; dan (8) menjadi guru adalah pelayanan (Sinamo, 2008:20). Namun demikian etos kerja guru SMP Negeri di Sektor 3 Kecamatan Jatibarang Kabupaten Indramayu ini tidak hanya dipengaruhi oleh pengembangan guru saja, ada faktor lain (epsilon), selain komunikasi organisasi yang juga berpengaruh, yang tidak dikaji dalam penelitian ini.

Dengan demikian, hasil penelitian ini mengindikasikan bahwa semakin tinggi (bagus) pengembangan guru guru SMP Negeri di Sektor 3 Kecamatan Jatibarang Kabupaten Indramayu, maka akan diikuti oleh semakin tingginya etos kerja guru. Hal ini dapat diterangkan oleh persamaan regresi $\mathrm{Y}=70,375+$ $0,790 X_{2}$. Dengan persamaan regresi tersebut dapat diinterpretasikan bahwa jika pengembangan guru $\left(\mathrm{X}_{2}\right)$ dan etos kerja guru $(\mathrm{Y})$ diukur dengan instrumen yang dikembangkan dalam penelitian ini, maka setiap perubahan skor pengembangan guru sebesar satu satuan dapat diestimasikan skor etos kerja guru akan berubah 0,790 satuan pada arah yang sama.

Berdasarkan temuan empirik yang menunjukkan adanya pengaruh yang signifikan pengembangan guru terhadap etos kerja guru, maka hasil penelitian ini memberikan beberapa informasi, di antaranya: (1) Pengembangan guru SMP Negeri di Sektor 3 Kecamatan Jatibarang Kabupaten Indramayu memberikan pengaruh yang berarti terhadap etos kerja guru, (2) Salah satu cara untuk meningkatkan etos kerja guru SMP Negeri di Sektor 3 Kecamatan Jatibarang Kabupaten Indramayu adalah dengan meningkatkan pengembangan guru, serta (3) Kontribusi yang diberikan oleh pengaruh pengembangan guru terhadap etos kerja guru adalah sebesar 36,1\%, sementara sisanya dipengaruhi oleh variabel lain, selain variabel komunikasi organisasi, yang tidak dikaji dalam penelitian ini (epsilon). 
(pelatihan),

(5) Inquiry (pemeriksaan)

Ketiga, adakah pengaruh komunikasi organisasi dan pengembangan guru secara simultan terhadap etos kerja guru SMP Negeri di Sektor 3 Kecamatan Jatibarang Kabupaten Indramayu. Secara empirik, hasil penelitian ini menginformasikan: (1) terdapat pengaruh yang signifikan komunikasi organisasi dan pengembangan guru secara simultan terhadap etos kerja guru SMP Negeri di Sektor 3 Kecamatan Jatibarang Kabupaten Indramayu, serta (2) besarnya pengaruh komunikasi organisasi dan pengembangan guru secara simultan terhadap etos kerja guru negeri SMP di Sektor 3 Kecamatan Jatibarang Kabupaten Indramayu ditunjukkan oleh hasil penelitian bahwa komunikasi organisasi yang terdiri dari dimensi: (1) "Downward communication" atau komunikasi kepada bawahan; (2) "Upward communication" atau komunikasi kepada atasan; (3) "Horizontal communication" atau komunikasi horizontal. Pendapat Muhammad (2000:108), serta pengembangan guru yang terdiri dari dimensi: (1) Individual guided staff development (pengembangan guru yang dipadu secara individual), (2) Observation/Assessment (observasi atau penilaian), (3) Involvement in a development/improvement process (keterlibatan dalam suatu proses pengembangan/peningkatan, (4) Training
(Castetter dalam Syaefudin, 2010:102), membawa implikasi yang signifikan terhadap etos kerja guru yang meliputi dimensi: (1) menjadi guru adalah rahmat; (2) menjadi guru adalah amanah; (3) menjadi guru adalah pangilan; (4) menjadi guru adalah aktualisasi; (5) menjadi guru adalah ibadah (6) menjadi guru adalah seni; (7) menjadi guru adalah kehormatan; dan (8) menjadi guru adalah pelayanan (Sinamo, 2008:20). Namun demikian etos kerja guru SMP Negeri di Sektor 3 Kecamatan Jatibarang Kabupaten Indramayu, tidak hanya dipengaruhi oleh komunikasi organisasi dan pengembangan guru guru saja, ada faktor lain (epsilon), yang juga berpengaruh, yang tidak dikaji dalam penelitian ini.

Menurut Sinungan

(2005:64) yang mengemukakan bahwa: 2 kelompok besar faktor-faktor yang mempengaruhi produktivitas, yang masing-masing faktor tersebut berlaku dalam cara yang berbeda dan dengan pengaruh yang berbeda dan dalam keadaan yang berbeda pula. Faktor yang dimaksud yaitu: (1) Kelompok kesatu: tingkat pendidikan dan keahlian, jenis teknologi dan hasil produksi, kondisi kerja, kesehatan, kemampuan fisik dan mental. (2) Kelompok kedua mencakup: Sikap (terhadap tugas), teman sejawat dan 
pengawas, keanekaragaman tugas,. sistem insentif, kepuasan kerja, kepastian pekerjaan, perspekrif dari ambisi dan promosi.

Dengan demikian, hasil penelitian ini mengindikasikan bahwa semakin bagus komunikasi organisasi dan pengembangan guru secara simultan pada SMP Negeri di Sektor 3 Kecamatan Jatibarang Kabupaten Indramayu, maka akan diikuti oleh semakin tingginya etos kerja guru. Hal ini dapat diterangkan oleh persamaan regresi $\hat{Y}=58,684+0,343 X_{1}$ $+0,268 X_{2}$. Dengan persamaan regresi tersebut dapat diinterpretasikan bahwa jika komunikasi organisasi $\left(\mathrm{X}_{1}\right)$, dan pengembangan guru $\left(\mathrm{X}_{2}\right)$ serta etos kerja guru (Y) diukur dengan instrumen yang dikembangkan dalam penelitian ini, maka setiap perubahan skor pelaksanaan komunikasi organisasi, dan pengembangan guru secara simultan sebesar satu satuan dapat diestimasikan skor etos kerja guru akan berubah 0,343 dan 0,268 satuan pada arah yang sama.

Berdasarkan temuan empirik yang menunjukkan adanya pengaruh yang signifikan komunikasi organisasi dan pengembangan guru terhadap etos kerja guru, maka hasil penelitian ini memberikan beberapa informasi, di antaranya: (1) Pelaksanaan komunikasi organisasi dan pengembangan guru pada
SMP Negeri di Sektor 3 Kecamatan Jatibarang Kabupaten Indramayu memberikan pengaruh yang berarti terhadap etos kerja guru SMP Negeri di Sektor 3 Kecamatan Jatibarang Kabupaten Indramayu, (2) Salah satu cara untuk meningkatkan etos kerja guru SMP Negeri di Sektor 3 Kecamatan Jatibarang Kabupaten Indramayu adalah dengan meningkatkan komunikasi organisasi dan pengembangan guru. (3) Kontribusi yang diberikan oleh komunikasi organisasi dan pengembangan guru secara bersamasama terhadap etos kerja guru SMP Negeri di Sektor 3 Kecamatan Jatibarang Kabupaten Indramayu adalah sebesar $36,7 \%$, sementara sisanya dipengaruhi oleh variabel lain, yang tidak dikaji dalam penelitian ini (epsilon).

\section{PENUTUP}

1) Terdapat pengaruh yang positif dan signifikan komunikasi organisasi terhadap etos kerja guru negeri SMP Negeri di Sektor 3 Kecamatan Jatibarang Kabupaten Indramayu. Adapun besaran pengaruhnya setelah melalui perhitungan regresi parsial adalah sebesar $22 \%$, 
sementara selebihnya sebanyak $78 \%$ merupakan pengaruh lain.

2) Terdapat pengaruh yang positif dan signifikan pengembangan guru terhadap etos kerja guru SMP Negeri di Sektor 3 Kecamatan Jatibarang Kabupaten Indramayu. Adapun besaran pengaruhnya setelah melalui perhitungan regresi parsial adalah sebesar 36,1 \%, sementara selebihnya sebanyak $63,9 \quad \%$ merupakan pengaruh lain.

3) Terdapat pengaruh yang positif dan signifikan komunikasi organisasi dan pengembangan guru secara simultan terhadap etos kerja guru SMP Negeri di Sektor 3 Kecamatan Jatibarang Kabupaten Indramayu. Adapun besaran pengaruhnya setelah melalui perhitungan regresi ganda adalah sebesar 36,7 \%, sementara selebihnya sebanyak $63,3 \%$ merupakan pengaruh lain.

\section{UCAPAN TERIMAKASIH}

Terimkasih kepada semua pihak yang telah membantu penulisan karya ilmiah ini.

\section{DAFTAR PUSTAKA}

Anoraga, Pandji. (2006). Psikologi Kerja.
Jakarta: PT. Rineka Cipta.

Arikunto, Suharsimi. (2006). Prosedur PenelitianSuatu Pendekatan Praktik. Jakarta: PT Asdi Mahasatya.

Djohar MS. (2006). Guru, Pendidik dan Pembinaannya, Yogyakarta: Grafica Indah.

Gomes, Faustino Cardoso. (2005). Manajemen Sumber Daya Manusia. Yogyakarta: Andi Offset.

Kunandar. (2007). Guru Profesional, Impelementasi Kurikulum Tingkat satuan pendidikan (KTSP) dan Sukses dalam sertifikasi Guru, Penerbit Rajawali Pers.

Muhammad, Arni. (2000). Komunikasi Organisasi. Jakarta: Bumi Aksara.

Nawawi, Hadari. (2002). Manajemen SDM Untuk Bisnis yang Kompetitif. Yogyakarta: Gajah Mada Univ. Press.

Ndraha,Talizduhu. (2002). Pengantar Teori Pengembangan Sumber Daya Manusia. Jakarta: PT.Rineka Cipta.

Mulyasa E.(2003). Manajemen Berbasis Sekolah, Konsep, Strategi dan Penerapan. Bandung: Remaja Rosdakarya.

Rahmadi, F. (2005). Publik Relation dalam Teori dan Praktek, Jakarta: Gramedia

Robins, S.P. (2001). Organizational behavior Conceps Controversies and Applications. London: 
Practice-Hall International, inc.

Sinamo, Jansen H. (2008). .Delapan

Etos Kerja Profesional.

Jakarta:Institut Darma

Mahardika.

Sinungan, Muchdarsyah. (2005).

Produktivitas Apa dan

Bagaimana. Jakarta: Bumi

Aksara.

Sudjana, Nana. (2004). Dasar-dasar Proses Belajar Mengajar, Bandung: SinarBaru.

Tasmara, Toto. (2002). Membudayakan Etos Kerja Islami, Jakarta:Gema Insani Press.

Toha, Mitfah. (2003). Prilaku Organisasi Konsep Dasar dan Aplikasinya, Jakarta: CV Rajawali.

Zamroni. (2000). Paradigma Pendidikan Masa Depan, Yogyakarta:

Bigraf Pubilshing. 